\title{
PENGARUH PEMANFAATAN TEKNOLOGI INFORMASI TERHADAP KUALITAS PELAYANAN PEGAWAI ADMINISTRASI DAN PENGARUH KUALITAS PELAYANAN PEGAWAI ADMINISTRASI TERHADAP KEPUASAN MAHASISWA DI LINGKUNGAN FISE UNY
}

\author{
Oleh \\ Diana Rahmawati ${ }^{1}$
}

\begin{abstract}
Abstrak
Penelitian ini bertujuan untuk mengetahui : (1) Pengaruh pemanfaatan teknologi informasi terhadap kualitas pelayanan pegawai administrasi di lingkungan FISE UNY. (2) Pengaruh kualitas pelayanan pegawai administrasi terhadap kepuasan mahasiswa di lingkungan FISE UNY

Penelitian ini menggunakan populasi pegawai administrasi FISE UNY sebanyak 50 orang untuk menjawab fenomena hipotesis pertama. Dari kuisioner yang disebar pada seluruh karyawan diperoleh hasil 33 kuesioner yang dapat digunakan dengan respon rate $66 \%$. Jumlah kuesioner tersebut tidak dapat memenuhi jumlah sampel minimal yang dapat digunakan dalam analisis. Penggunanan sampel sebanyak 33 merupakan keterbatasan dari penelitian ini mengingat kuesioner sudah disebarkan kepada seluruh populasi pegawai administrasi sehingga sampel tidak dapat ditambah. Sedangkan untuk hipotesis kedua, penelitian ini menggunakan sampel sebanyak 133 mahasiswa dari seluruh program studi. Ukuran sampel minimum ditentukan dengan jumlah variabel latent yang paling komplek dikalikan dengan 10 dan dengan melakukan analisis power secara priori. Pengujian reliabilitas menggunakan PLS dimana reliabilitas dilihat dari hasil nilai composite reliability nilai hubungan antar variabel dengan dimensi pengukur lebih dari 0,7 dan dengan menggukan Cronbach's alpha minimal 0,7. Validitas instrumen diuji menggunakan validitas konvergen dan validitas diskriminan. Konstruk dianggap memenuhi validitas konvergen jika nilai ratarata varian (Average variance extracted $-A V E$ ) mempunyai nilai lebih dari 0,5 mempunyai loading factor minimal 0,60 dan idelanya 0,70 atau lebih. Pengujian model penelitian menggunakan teknik analisis second order dalam PLS dan hipotesis yang diajukan dalam penelitian ini (hipotesis pertama dan kedua) diuji dengan menggunakan teknik Partial-leastsquare (PLS).

Hasil penelitian ini menyatakan bahwa (1) Pemanfaatan Teknologi Informasi tidak Berpengaruh Terhadap Kualitas Pelayanan Pegawai Administrasi Di Lingkungan FISE UNY. Hal ini ditunjukkan dengan nilai koefisien sebesar -0,00223, nilai t-value sebesar 0,899123 dan nilai p-value sebesar 0,3707. Dan (2) Kualitas Pelayanan Pegawai Administrasi Berpengaruh Terhadap Kepuasan Mahasiswa Di Lingkungan FISE UNY. Hal ini ditunjukkan dengan nilai koefisien 0,787333 nilai t-value sebesar 41,072917 dan nilai p-value sebesar 0,0000 .
\end{abstract}

Kata Kunci : Pemanfaatan Teknologi Informasi, Kualitas Pelayanan Pegawai Administrasi dan Kepuasan Mahasiswa.

\footnotetext{
${ }^{1}$ Dosen Jurusan Pendidikan Akuntansi - Universitas Negeri Yogyakarta
} 


\section{PENDAHULUAN}

\subsection{Latar belakang masalah}

Teknologi informasi meliputi teknologi komputer (computing technology) dan teknologi jaringan yang digunakan untuk memproses dan menyebarkan informasi baik itu yang bersifat finansial atau non finansial (Bodnar dan Hopwood, 1995). Sehingga dapat dikatakan bahwa Teknologi informasi adalah segala cara atau alat yang terintegrasi yang digunakan untuk menjaring data, mengolah dan mengirimkan atau menyajikan secara elektronik menjadi informasi dalam berbagai format yang bermanfaat bagi pemakainya. Teknologi informasi khususnya teknologi komputer sangat berpotensi untuk memperbaiki performa individu dan organisasi, karenanya banyak pengambil keputusan menginvestasikan dana untuk teknologi informasi. Tetapi harus disadari bahwa investasi di bidang teknologi informasi membutuhkan dana yang besar. Roach (1991) dan Strassman (1996) memberikan bukti bahwa investasi dibidang teknologi informasi membutuhkan dana yang besar dan akan mengalami peningkatan dari tahun ke tahun. Besarnya dana yang dikeluarkan perusahaan dalam investasi dibidang teknologi informasi mengharuskan organisasi memanfaatkan teknologi informasi secara optimal. Menurut Teddy Jurnali (2001), besarnya dana yang diinvestasikan dan kemungkinan timbulnya resiko dalam pemanfaatan teknologi informasi khususnya pengembangan sistem informasi pada suatu organisasi menyebabkan pengembang sistem informasi perlu memahami faktor-faktor yang dapat mengarahkan anggota organisasi untuk menggunakan sistem informasi secara efektif. Para manajer dan pegawai operasional harus dapat menggunakan aplikasi-aplikasi yang tersedia, mempelajari secara langsung aspek perangkat keras dan perangkat lunak serta mengadopsi teknologi informasi sesuai dengan kebutuhan tugasnya. Pemanfaatan teknologi informasi oleh seluruh anggota organisasi termasuk para karyawan merupakan salah satu pengukur kesuksesan pengembangan sistem informasi pada organisasi yang bersangkutan.

Pemanfaatan teknologi informasi merupakan sarana penunjang/pendorong bagi organisasi dalam mencapai tujuan organisasi.. Pemanfaatan teknologi informasi dapat dilakukan secara efektif jika anggota dalam organisasi dapat menggunakan teknologi tersebut dengan baik. Pemanfaatan teknologi yang efektif dapat meningkatkan kinerja. Hal ini sesuai dengan model penerimaan teknologi (technology acceptance model / TAM). TAM (Technology Acceptance Model) menyatakan bahwa pemanfaatan teknologi informasi dapat meningkatkan kinerja. Kinerja berhubungan dengan pencapaian serangkaian tugas-tugas yang dilaksanakan oleh individu individu didalam organisasi (Thai FJ ; 2002). Sehingga, semakin tinggi kinerja individu semakin meningkat pula efektifitas, produktivitas dan kualitas pelayanan individu tersebut.

Kualitas pelayanan berhubungan dengan kecocokan antara produk layanan dengan kebutuhan dari pengguna pelayanan tersebut (Mahendra, 2008). Kualitas pelayanan dapat diartikan sebagai persepsi pengguna layanan mengenai baik buruknya suatu layanan dan atau diterima tidaknya suatu layanan. Dari definisi diatas dapat disimpulkan bahwa kualitas layanan merupakan persepsi pengguna layanan mengenai layanan yang diberikan oleh seorang individu. Penelitian mengenai kualitas pelayanan dilakukan oleh Scotti (2007) yang menemukan bahwa kualitas pelayanan berhubungan dengan kepuasan konsumen. Konsumen yang puas akan menggunakan kembali layanan dan menyarankan orang lain untuk menggunakan layanan tersebut. Dalam konteks penelitian ini yang dimaksud dengan kualitas pelayanan adalah kualitas pelayanan yang diberikan oleh pegawai administrasi Fakultas Ilmu Sosial dan Ekonomi Universitas Negeri Yogyakarta. Pelayanan pegawai administrasi meliputi segala sesuatu yang berkaitan dengan tugas-tugas administrasi yang dilaksanakan 
pegawai khususnya yang berkaitan dengan pelayanan kepada mahasiswa baik dibidang akademik, keuangan maupun bidang administrasi umum lainnya. Sedangkan kepuasan dalam konteks penelitian ini adalah kepuasan mahasiswa yang merupakan pengguna utama layanan pegawai administrasi.

Penelitian yang dilakukan oleh Sukanti (2008) mengenai kepuasan mahasiswa program studi pendidikan akuntansi tentang peran pegawai administrasi di lingkungan Fakultas Ilmu Sosial dan Ekonomi (FISE) UNY menemukan bahwa kepuasan mahasiswa terhadap pelayanan tenaga non akademik (pegawai administrasi) dalam kategori kurang / rendah. Hal ini berarti bahwa mahasiswa merasa tidak puas/ kurang puas terhadap pelayanan yang diberikan pegawai administrasi di lingkungan FISE UNY. Berdasarkan penelitian yang dilakukan Sukanti, penelitian ini ingin meneliti kembali mengenai persepsi mahasiswa terhadap kualitas pelayanan tenaga administrasi di lingkungan FISE UNY jika kualitas pelayanan tenaga administrasi tersebut di laksanakan dengan memanfaatkan teknologi informasi. Disamping itu penelitian ini dilakukan dalam rangka mendukung program FISE UNY yang berkomitmen memberikan pelayanan prima bagi konsumen yaitu mahasiswa, sehingga penelitian ini berjudul "Pengaruh Pemanfaatan Teknologi Informasi Terhadap Kualitas Pelayanan Pegawai Administrasi dan Pengaruh Kualitas Pelayanan Pegawai Administrasi Terhadap Kepuasan Mahasiswa Di Lingkungan FISE UNY”.

\subsection{Rumusan masalah}

Berdasarkan uraian latar belakang masalah diatas maka perumusan pertanyaan masalah penelitian ini adalah sebagai berikut:

1. Apakah pemanfaatan teknologi informasi berpengaruh terhadap kualitas pelayanan pegawai administrasi di lingkungan FISE UNY?

2. Apakah kualitas pelayanan pegawai administrasi berpengaruh terhadap kepuasan mahasiswa di lingkungan FISE UNY?

\subsection{Tujuan penelitian}

Sesuai dengan pertanyaan masalah tersebut diatas, maka penelitian ini bertujun untuk mengetahui :

1. Pengaruh pemanfaatan teknologi informasi terhadap kualitas pelayanan pegawai administrasi di lingkungan FISE UNY.

2. Pengaruh kualitas pelayanan pegawai administrasi terhadap kepuasan mahasiswa di lingkungan FISE UNY?

\subsection{Manfaat penelitian}

Penelitian ini memberikan kontribusi pemahaman yang lebih komprehensif mengenai pengaruh pemanfaatan teknologi informasi terhadap kualitas pelayanan dan pengaruh kualitas pelayanan itu sendiri terhadap kepuasan mahasiswa. Penelitian ini juga membuka wawasan para anggota organisasi (dalam hal ini FISE UNY) mengenai pentingnya pemahaman tentang pemanfaatan teknologi informasi secara efektif untuk meningkatkan kualitas pelayanan. Disamping itu, hasil penelitian ini dapat dijadikan pertimbangan bagi pihak top manajemen fakultas untuk pengambilan keputusan dalam memberikan pelayanan prima pada konsumen yaitu mahasiswa sehingga kepuasan mahasiswa dapat terpenuhi.

\subsection{Tinjauan Pustaka}

\subsubsection{Pemanfaatan Teknologi Informasi}

Teknologi informasi meliputi segala cara atau alat yang terintegrasi yang digunakan untuk menjaring data, mengolah dan mengirimkan atau menyajikan secara elektronik menjadi informasi dalam berbagai format yang bermanfaat bagi pemakainya. Thompson et al (1991; 
1994) mendefinisikan pemanfaatan teknologi sebagai manfaat yang diharapkan oleh pengguna sistem informasi dalam melaksanakan tugasnya dimana pengukurannya berdasarkan pada intensitas pemanfaatan, frekuensi pemanfaatan dan jumlah aplikasi atau perangkat lunak yang digunakan. Pemanfaatan teknologi informasi merupakan sarana penunjang/pendorong bagi organisasi dalam mencapai tujuan organisasi. Romney (2006) menyatakan bahwa pemanfaatan teknologi informasi didalam organisasi akan mempengaruhi aktivitas-aktivitas/proses bisnis yang terdapat dalam organisasi tersebut. Adapun pengaruh pemanfaatan teknologi informasi dalam organisasi dapat dilihat dari dampak pemanfaatan teknologi informasi pada rantai nilai organisasi (value chain).

Dampak strategis pemanfaatan teknologi informasi bagi organisasi dapat dilihat dari dapat tidaknya teknologi informasi menunjang dan membantu organisasi dalam melaksanakan dan mencapai strategi organisasi secara keseluruhan. Hal tersebut sesuai dengan apa yang dikemukan oleh Romney (2006) bahwa pemanfaaatan teknologi informasi didalam organisasi bukan merupakan strategi dasar dari organisasi tersebut, implementasi teknologi informasi digunakan untuk membantu dalam pencapaian strategi organisasi. Dengan memanfaatkan teknologi informasi, akses terhadap proses bisnis perusahaan dapat dilakukan dengan cepat sehingga pengambilan keputusan dapat dilakukan secara lebih cepat dan akurat dan pada akhirnya tujuan organisasi dapat tercapai.

\subsubsection{Kualitas Pelayanan}

Konsep kualitas pelayanan berasal dari berbagai riset dibidang pemasaran. Konsep mengenai kualitas pelayanan itu sendiri dipahami secara berbeda yaitu antara harapan pengguna dengan persepsi dari pengguna dan persepsi dari kinerja pelayanan. Kualitas pelayanan menurut persepsi pengguna adalah anggapan pengguna mengenai baik buruknya pelayanan yang diterima oleh pengguna. Sedangkan kualitas pelayanan menurut persepsi dari kinerja pelayanan adalah memberikan pelayanan yang terbaik/pelayanan prima dari sumber daya yng di miliki oleh penyedia layanan. Mahendra (2008) mengemukakan bahwa kualitas pelayanan berhubungan dengan kecocokan antara produk layanan dengan kebutuhan dari pengguna pelayanan tersebut. Kualitas pelayanan dapat diartikan sebagai persepsi pengguna layanan mengenai baik buruknya suatu layanan dan atau diterima tidaknya suatu layanan oleh pengguna.

Kualitas pelayanan yang dimaksud dalam konteks penelitian ini adalah kualitas pelayanan yang diberikan oleh pegawai administrasi Fakultas Ilmu Sosial dan Ekonomi Universitas Negeri Yogyakarta. Pelayanan pegawai administrasi meliputi segala sesuatu yang berkaitan dengan tugas-tugas administrasi yang dilaksanakan pegawai khususnya yang berkaitan dengan pelayanan kepada mahasiswa baik dibidang akademik, keuangan maupun bidang administrasi umum lainnya. Gronroons (1988) dalam Banwet dan Datta (2002) menyatakan bahwa kualitas pelayanan secara garis besar dibagi menjadi dua dimensi yaitu kualitas tehnis (outcome) dan dimensi fungsional (proses). Kualitas tehnis atau kualitas tangible dapat ditunjukkan dengan jumlah sarana dan prasaranan yang disediakan organisasi. Sedangkan kualitas fungsional mengacu pada proses penyampaian pelayanan. Penerimaan kualitas pelayanan terjadi ketika kinerja bertemu dengan ekpektasi konsumen. Dalam konteks penelitian ini dapat dikatakan bahwa penerimaan kualitas pelayanan pegawai administrasi terjadi jika memenuhi harapan, keinginan dan kebutuhan dari mahasiswa sehingga mahasiswa merasa puas dengan pelayanan tersebut. Peran dari pegawai administrasi terdapat pada dimensi fungsional (proses). Penelitian psikologis (Barger dan Grandey, 2006; Zajonc, 1985 dalam Barger Grandey, 2006) mengemukakan bahwa empati pegawai bagian pelayanan dapat meningkatkan kepuasan konsumen. Pegawai yang tersenyum kepada konsumen akan membuat konsumen tersenyum juga karena efek psikologis. 


\subsubsection{Kepuasan Konsumen (Mahasiswa)}

Kepuasan kosumen menurut Kottler (dalam Tjiptono,1997) dalam tatugasakhir.blogspot.com/2007/ adalah tingkat perasaan seseorang setelah membandingkan kinerja atau hasil yang ia rasakan dibandingkan dengan harapannya. Sedangkan Wilkie (dalam Tjiptono,1997) dalam ta-tugasakhir.blogspot.com/2007/ mendefinisikan kepuasan pelanggan sebagai suatu tanggapan emosial pada evaluasi terhadap pengalaman konsumsi suatu produk atau jasa. Kepuasan konsumen merupakan perbedaan antara yang diharapkan konsumen (nilai harapan) dengan situasi yang diberikan perusahaan (perguruan tinggi) di dalam usaha memenuhi harapan konsumen (mahasiswa) ta-tugasakhir.blogspot.com/2007/. Sedangkan bertemunya harapan konsumen dengan pelayanan yang diberikan perusahaan merupakan penerimaan kualitas pelayanan itu sendiri sehingga dapat disimpulkan yang dimaksud dengan kepuasan konsumen adalah besarnya tingkat penerimaan kualitas pelayanan yang diberikan oleh perusahaan kepada konsumen. Dalam konteks penelitian ini yang dimaksud dengan kepuasan mahasiswa adalah besarnya tingkat penerimaan kualitas pelayanan yang diberikan pegawai administrasi kepada mahasiswa di lingkungan FISE UNY.

Konsumen yang merasa puas oleh Kottler (1996) dalam ta-tugas

akhir.blogspot.com/2007/ mempunyai ciri-ciri sebagai berikut:

1.melakukan pembelian ulang

2. mengatakan hal-hal yang baik tentang perusahaan kepada orang lain.

3. kurang memperhatikan merek ataupun iklan produk pesaing

4. membeli produk yang lain dari perusahaan yang sama

Menurut Tjiptono $(1996 ; 78)$ penerapan kualitas jasa secara konsisten akan menumbuhkan kepuasan pelanggan/konsumen dan memberikan dampak positif bagi perusahaan antara lain :

1. adanya keharmonisan hubungan antara pelanggan dengan perusahaan

2. memberikan kesan yang baik bagi pelanggan untuk melakukan pembelian ulang

3. terciptanya loyalitas pelanggan

4. membentuk rekomendasi dari pelanggan kepada orang lain yang menguntungkan pihak perusahan (dari mulut ke mulut)

5. terbentuknya reputasi yang baik dimata pelanggan yang pada akhirnya

6. meningkatnya laba perusahaan.

\subsubsection{Pengembangan Hipotesis}

\section{Hubungan Pemanfaatan Teknologi Informasi-Kualitas Pelayanan}

Hubungan pemanfaatan teknolog informasi dan kualitas pelayanan berdasarkan pada Theory of Reasoned Action (TRA) yang menyatakan bahwa seseorang akan menggunakan teknologi informasi jika teknologi tersebut bermanfaat dan dapat meningkatkan kinerja dari orang tersebut. Disamping itu didasarkan pula pada Technology serangkaian Acceptance Model (TAM) yang menyatakan bahwa pemanfaatan teknologi informasi dapat meningkatkan kinerja. Sedangkan kinerja oleh Thai FJ (2002) didefinisikan sebagai pencapaian tugas-tugas yang dilakukan/dilaksanakan oleh individu didalam organisasi sesuai dengan deskripsi tugas dan tanggung jawabnya didalam organisasi tersebut Semakin tinggi kinerja individu semakin meningkat pula efektifitas, produktivitas dan kualitas pelayanan individu tersebut. Sehingga dapat dikatakan bahwa pemanfaatan teknologi informasi didalam suatu organisasi akan meningkatkan kualitas pelayanan individu tersebut dalam pelaksanaan tugas sehari-harinya. Pemanfaatan teknologi informasi diharapkan menjadi faktor yang berpengaruh dalam pencapaian kualitas pelayanan individu tersebut pada pelaksanaan tugasnya didalam organisasi.

Berdasarkan deskripsi hubungan pemanfaatan teknologi informasi dengan kualitas pelayanan tersebut diatas maka hipotesis yang dikembangkan dalam penelitian ini adalah: 


\section{H1 : Pemanfaatan Teknologi Informasi Berpengaruh Terhadap Kualitas Pelayanan Pegawai Administrasi Di Lingkungan FISE UNY}

\section{Hubungan Kualitas Pelayanan-Kepuasan Mahasiswa}

Hubungan kualitas pelayanan dan kepuasan mahasiswa berdasarkan pada penelitian yang dilakukan oleh Scotti (2007) mengenai hubungan antara kinerja dengan lingkungan kerja, kualitas pelayanan dan kepuasan konsumen. Salah satu hasil penelitian Scotti menemukan bahwa kualitas pelayanan berhubungan dengan kepuasan konsumen. Kepuasan konsumen terjadi jika konsumen menggunakan kembali layanan dan menyarankan orang lain untuk menggunakan layanan tersebut. Kepuasan konsumen dalam konteks penelitian ini adalah kepuasan mahasiswa yang merupakan pengguna utama layanan pegawai administrasi.

Berdasarkan penelitian tersebut diatas dapat diambil kesimpulan bahwa kepuasan konsumen ditentukan persepsi konsumen terhadap baik buruknya kualitas pelayanan yang diberikan oleh individu dalam organisasi (pegawai) tersebut. Sehingga hipotesis yang ingin dikembangkan dalam penelitian ini adalah:

\section{H2: Kualitas Pelayanan Pegawai Administrasi Berpengaruh Terhadap Kepuasan Mahasiswa Di Lingkungan FISE UNY}

\subsubsection{Model Penelitian}

Berdasarkan pengembangan hipotesis diatas maka model penelitian atau paradigma penelitian dalam penelitian ini model penelitian digambarkan pada gambar 1 .

\section{Model Penelitian}

\begin{tabular}{|c|c|c|}
\hline $\begin{array}{c}\text { Pemanfaatan } \\
\text { Teknologi } \\
\text { Informasi }\end{array}$ & $\begin{array}{c}\text { Kualitas } \\
\text { Pelayanan } \\
\text { Pegawai } \\
\text { Administrasi }\end{array}$ & $\begin{array}{c}\text { Kepuasan } \\
\text { Mahasiswa }\end{array}$ \\
\hline
\end{tabular}

\section{METODE PENELITIAN}

\subsection{Definisi Operasional Variabel}

\section{Pemanfaatan Teknologi Informasi}

Pemanfaatan teknologi informasi merupakan penggunaan / interaksi antara pegawai administrasi dan teknologi informasi untuk memberikan pelayanan kepada mahasiswa. Pemanfaatan diukur dengan penggunaan nyata yang diukur menggunakan pertanyaan mengenai frekuensi penggunaan teknologi informasi dan lama waktu penggunaan teknologi informasi dalam melayani mahasiswa. Item pertanyaan mengadopsi dari penelitian Iivari (2005) dengan disesuaikan dengan konteks penelitian. Pemanfaatan teknologi informasi diukur menggunakan skala Likert 1-7.

\section{Kualitas Pelayanan}

Kualitas pelayanan adalah tingkat baik atau buruknya suatu pelayanan yang diberikan oleh pegawai administrasi kepada mahasiswa. Kualitas pelayanan dalam penelitian ini mengacu pada pelayanan fungsional sebagai bagian dari pelayanan secara keseluruhan kepada mahasiswa. Kualitas pelayanan diukur dengan menggunakan kualitas pelayanan (SERVQUAL -reliability, responsiveness, assurance, empathy, Tangible) (Sahu, 2006; Hauser dan Paul,2006). Instrument SERVQUAL dapat digunakan dengan sempurna dan bernilai secara potensial (Quinn, 1997) Dalam penelitian ini, untuk mengukur kualitas pelayanan staff administrasi, digunakan empat dimensi SERVQUAL yaitu reliability, responsiveness, assurance, empathy, dan menghilangkan tangible. Tidak digunakan tangible 
karena tangible berfungsi untuk mengukur kualitas pelayanan dari sisi fasilitas fisik yang merupakan pelayanan teknis bukan merupakan pelayanan fungsional yang diteliti dalam penelitian ini. Pertanyaan yang dikembangkan disesuaikan dengan penerapan pada pelayanan pegawai administrasi sesuai dengan konteks penelitian. Instrumen survei menggunakan skala Likert 1-7.

\section{Kepuasan Mahasiswa}

Kepuasan mahasiswa adalah derajat perasaan puas mahasiswa terhadap pelayanan yang diberikan staf administrasi kepada mahasiswa. Kepuasan pelayanan diukur dengan kepuasan keseluruhan yang diadopsi dari penelitian pengaruh penggunaan teknologi yang bersifat swalayan terhadap kepuasan secara keseluruhan yang dilakukan Beatson et. al (2006). Untuk mengukur kepuasan pelayanan penelitian mengadopsi instrumen pengukuran kepuasan secara keseluruhan yang digunakan Beatson et. al (2006) yang disesuaikan dengan konteks penelitian. Instrumen dikembangkan dengan menggunakan skala Likert 1-7.

\subsection{Populasi dan Sampel Penelitian}

Populasi dalam penelitian ini menggunakan mahasiswa FISE UNY dan pegawai administrasi FISE UNY yang berhubungan dengan pelayanan mahasiswa. Responden mahasiswa FISE UNY digunakan untuk mengukur kualitas pelayanan yang diberikan oleh pegawai administrasi dan tingkat kepuasan atas pelayanan yang diberikan tersebut. Responden pegawai administrasi digunakan untuk mengetahui intensitas pemanfaatan teknologi informasi dalam memberikan pelayanan kepada mahasiswa. Pemilihan sampel untuk mahasiswa FISE UNY dilakukan dalam penelitian ini mengingat besarnya populasi mahasiswa FISE UNY. Sedangkan untuk pegawai administrasi FISE UNY menggunakan populasi karena relatif sedikitnya jumlah pegawai administrasi FISE UNY yaitu 50 pegawai. Metode purposive sampling digunakan dalam penelitian ini.

Ukuran sampel minimum ditentukan dengan jumlah variabel latent yang paling komplek dikalikan dengan 10 (Gefen, et al. 2000) dan dengan melakukan analisis power secara priori. Analisis power priori menggunakan nilai 0.80 dengan alpha 0.5 cukup untuk penelitian bisnis (Hair et al., 1995) menggunakan variabel latent yang paling komplek. Analisis power bertujuan untuk menghindari error statistik tipe 1 dan tipe 2 (Erdfelder, et al. 1996). Ukuran efek (effect size) pada sebagian besar aplikasi paling tidak "small" (Cohen, 1977, 1988 dalam Erdfelder, et al. 1996) untuk memperoleh signifikansi praktis. Ukuran efek mengukur derajat keberadaan fenomena yang sedang diteliti pada populasi (Hair el al., 1995). Dengan kata lain, semakin kecil keyakinan peneliti terhadap kemampuan sampel menangkap fenomena pada populasi maka ukuran efek yang digunakan semakin kecil pula. Hair et al. (1995) memaparkan ukuran efek yang digunakan Cohen (1988) dalam kategori "small", medium" dan "large" dengan nilai 0.2, 0.5 dan 0.8. Analis power dilakukan dengan harapan mampu meningkatkan kekuatan hasil signifikansi uji. Dengan mempertimbangkan kedua aspek tersebut, maka jumlah sampel minimum yang dibutuhkan untuk analisis adalah 70 (jumlah variabel latent yang paling komplek 5, analisis power dengan power 80 dan df. 0.05 menunjukan sampel minimal yang dibutuhkan 70). Perhitungan jumlah sampel mengunakan perangkat lunak G*Power 3.0.10 yang dikembangkan oleh Heinrich-Heine-Universität Institut für experimentelle Psychologie yang tersedia pada website http://www.psycho.uniduesseldorf.de.

\subsection{Instrumen Penelitian}


Penyusunan instrumen dalam penelitian ini mengacu pada penelitian yang terdahulu dan disesuaikan dengan konteks penelitian ini. Untuk mengukur Pemanfaatan Teknologi Informasi mengacu pada instrumen yang dikembangkan oleh Iivari (2005) sedangkan Kualitas Pelayanan mengadopsi instrumen yang dikembangkan oleh Sahu (2006) dan Hauser dan Paul (2006) serta Kepuasan Mahasiswa mengacu pada instrumen yang dikembangkan oleh Beatson et. al (2006). Item pertanyaan yang dikembangkan dalam penelitian ini menggunakan skala likert 1-7. Penggunaan skala likert 1-7 dimaksudkan untuk menfokuskan kecenderungan jawaban dari responden yang berada di tengah yang berupa ragu-ragu atau sedang. Instrumen Pemanfaatan teknologi informasi diukur dengan skala likert 1-7 yang menunjukkan frekuensi penggunaan nyata dari teknologi informasi dari tidak pernah sampai dengan selalu/sering. Instrumen Kualitas Pelayanan diukur dengan skala likert mengenai kesetujuan atau ketidak setujuan terhadap pernyataan -pernyataan dalam item pertanyaan mulai sangat tidak setuju sampai dengan sangat setuju. Instrumen Kepuasan Mahasiswa menunjukkan puas tidaknya mahasiswa terhadap pelayanan yang diberikan dari tidak puas sampai dengan puas. Berikut dibawah ini tabel mengenai kisi-kisi instrumen yan digunakan dalam penelitian ini :

\section{Tabel 1}

Kisi-Kisi Instrumen Penelitian

\begin{tabular}{|c|l|l|l|}
\hline No & \multicolumn{1}{|c|}{ Variabel } & \multicolumn{1}{c|}{ Indikator } & \multicolumn{1}{c|}{ No Item } \\
\hline 1 & $\begin{array}{l}\text { Pemanfaatan } \\
\text { Teknologi Informasi }\end{array}$ & $\begin{array}{l}\text { Penggunaan nyata dari } \\
\text { teknologi informasi } \\
\text { (komputer) }\end{array}$ & 8 dan 9 \\
\hline 2 & Kualitas Pelayanan & Reliability & $3,4,5$ \\
\hline & & Responsiveness & $6,7,8$ \\
\hline & & Assurance & $9,10,11,12$ \\
\hline & & Empathy & $13,14,15,16$ \\
\hline 3 & Kepuasan Mahasiswa & Kepuasan pelayanan & 17 \\
\hline
\end{tabular}

\subsection{Tehnik Analisis}

\section{Uji Validitas dan Reliabilitas}

Uji validitas dan reliabilitas dimaksudkan untuk mengukur kelayakan instrumen yang akan digunakan untuk penelitian. Untuk menguji validitas dan reliabilitas instrumen dilakukan pengujian awal dengan menguji hubungan antar konstruk dengan indikator (outer model).

Pada analisis menggunakan PLS reliabilitas dilihat dari hasil nilai composite reliability nilai hubungan antar variabel dengan dimensi pengukur lebih dari 0,7 dan dengan menggukan Cronbach's alpha minimal 0,7 (Hair et al., 1995).

Validitas instrumen diuji menggunakan validitas konvergen dan validitas diskriminan. Konstruk dianggap memenuhi validitas konvergen jika nilai rata-rata varian (Average variance extracted - AVE) mempunyai nilai lebih dari 0,5 mempunyai loading factor minimal 0,60 dan idelanya 0,70 atau lebih (Chin, 1998). Penelitian ini menggunakan loading paling tidak 0,70 untuk analisis data dan memiliki nilai communality paling tidak 0.5. Konstruk dianggap memenuhi validitas diskriminan jika nilai loading antara variabel laten dengan indikatornya lebih tinggi daripada loading indikator tersebut dengan variabel laten lain. Untuk mengetahui pemenuhan validitas diskriminan dalam analisis PLS dapat dengan membandingkan nilai korelasi indikator suatu konstruk memiliki nilai lebih tinggi dibandingkan dengan korelasi indikator tersebut dengan konstruk lain (cross loading)

\section{Pengujian Model Penelitian}


Pengujian model penelitian menggunakan teknik analisis second order dalam PLS. Penggunaan teknik bertujuan untuk mengetahui pengaruh komponen penyusun kontruk variabel laten terhadap model yang diajukan. Pengujian model dilakukan sekali. Pengambilan keputusan terhadap hipotesis dengan melihat signifikansi hubungan antar konstruk yang diukur (inner model) apakah berhubungan positif atau negatif.

\section{Pengujian Hipotesis}

Hipotesis yang diajukan diuji dengan menggunakan teknik Partial-least-square (PLS). Penggunaan PLS cocok untuk prediksi dan membangun teori, dan sampel yang dibutuhkan relatif kecil minimum 10 kali item konstruk yang paling komplek (Gefen et al., 2000). Keuntungan lain dari penggunaan PLS yang diungkapkan oleh Ho et al. (2003) adalah, pertama, PLS mengestimasi ukuran model pada validitas dan reliabilitas ukuran. Kedua, menggunakan indikator dari konstruk latent, PLS menghasilkan parameter dari model struktural yang menguji kekuatan dari hubungan yang dihipotesiskan. Menurut Temme et al (2006) PLS memeberikan nilai sebenarnya (true values) yang lebih baik daripada OLS. Data yang dianalisis dengan PLS tidak harus terdistribusi normal, PLS tidak mengasumsikan distribusi tertentu dan data PLS dapat menggunakan, nominal, kategorikal, ordinal, interval dan rasio. (Kustono, 2008). PLS tidak mensyaratkan dasar teori yang kuat sehingga tepat untuk penelitian untuk menguji dan / atau mengembangkan teori, PLS juga dapat digunakan pada data yang terkendala asumsi klasik (Jogiyanto dan Abdillah (2009).

\section{HASIL PENELITIAN DAN PEMBAHASAN}

\subsection{Deskripsi Responden}

Penelitian ini menggunakan pegawai administrasi FISE UNY sebayak 50 orang untuk menjawab fenomena hipotesis pertama. Dari kuisioner yang disebar pada seluruh karyawan diperoleh hasil 33 kuesioner yang dapat digunakan dengan respon rate $66 \%$. Jumlah kuesioner tersebut tidak dapat memenuhi jumlah sampel minimal (70) yang dapat digunakan dalam analisis. Penggunanan sampel sebanyak 33 merupakan keterbatasan dari penelitian ini mengingat kuesioner sudah disebarkan kepada seluruh populasi pegawai administrasi sehingga sampel tidak dapat ditambah. Sedangkan untuk hipotesis kedua, penelitian ini menggunakan sampel sebanyak 133 mahasiswa dari seluruh program studi.

Hasil survei kelompok responden mahasiswa menunjukan bahwa usia rata-rata responden mahasiswa adalah antara 19-20 tahun, rata-rata lama kuliah 1,51 tahun dan berinteraksi dengan pegawai administrasi rata-rata 2 kali dalam 1 bulan. Jenis kelamin mahasiswa pria $37 \%$ sedangkan wanita $63 \%$ dan sebagian besar mahasiswa sebanyak $79 \%$ berinteraksi dengan bagian administrasi adalah untuk mengurus kelengkapan akademik.

Hasil survey pada kelompok responden karyawan menunjukan usia rata-rata 36,86 tahun dan pengalaman menggunakan komputer rata-rata selama 11,16 tahun. Respoden karyawan terdiri dari $73 \%$ pria dan $7 \%$ wanita dengan tingkat pendidikan $50 \%$ responden adalah sarjana. Sebanyak $94 \%$ responden menggunakan komputer sebagai alat untuk membantu pekerjaan dan $100 \%$ responden menggunakan komputer sebagai alat yang digunakan untuk membantu pekerjaan yang bersifat administratif. Hasil survey juga menunjukkan bahwa sebagian besar dari responden ( $83 \%$ ) mengaku sering berinteraksi dengan mahasiswa dan 70 $\%$ responden menganggap mahasiswa cenderung bersikap kurang sopan.

\subsection{Validitas Dan Reliabilitas}

Sebelum uji hipotesis dilakukan pertama-tama dilakukan uji validitas dan reliabilitas untuk menguji kelayakan instrument. Uji validitas dan reliabilitas juga dilakukan untuk menguji indikator pertanyaan apakah item pertanyaan memenuhi syarat digunakan untuk uji hipotesis atau tidak. Dari hasil uji diketahui terdapat 5 item pertanyaan yang harus 
dikeluarkan sebagai alat ukur dalam uji hipotesis. Item pertanyaan tersebut yaitu 4 pertanyaan mengenai kuliatas pelayanan yang meliputi indikator assurance butir pertanyaan pertama, indikator emphaty butir pertanyaan ketiga, indikator reliability butir pertanyaan pertama, dan indikator responsiveness butir pertanyaan kedua dan item pertanyaan mengenai penggunaan TI pada butir pertanyaan kedua. Setelah seluruh item tersebut dikeluarkan dari daftar pertanyaan indikator, kemudian dilakukan uji hipotesis.

Hasil uji reliabilitas menunjukan cronbac alpha seluruh indikator memiliki nilai lebih 0,7 dan nilai composite reliability juga mempunyai nliai lebih dari 0,7 dari semua indikator yang digunakan. Seluruh nilai tersebut menujukkan bahwa instrumen yang digunakan telah memenuhi syarat reliabilitas. Di sisi lain, nilai AVE dari seluruh indikator memiliki nilai lebih dari 0,6 dan nilai commulality lebih dari 0,6. Dari hasil tersebut dapat dilihat bahawa instrumen penelitian telah memenuhi syarat validitas konvergen. Untuk melihat validiatas divergen dilakukan dengan cara melihat nilai cross loading. Instrumen dianggap memenuhi validitas divergen jika korelasi indikator suatu konstruk memiliki nilai lebih tinggi dibandingkan dengan korelasi indikator tersebut dengan konstruk lain (cross loading). Dari hasil analisis dapat dilihat bahwa seluruh korelasi indikator suatu konstruk memiliki nilai lebih tinggi dibandingkan dengan korelasi indikator tersebut dengan konstruk lain Dari hasil analisa tersebut dapat disimpulakan bahwa instrumen yang digunakan dalam penelitian ini memenuhi syarat validitas dan reliabilitas.

\subsection{Hasil Uji Model Dan Uji Hipotesis}

Uji model dan uji hipotesis menggunakan teknik Second Order .Penggunaan teknik second order dimaksudkan untuk mengetahui komponen mana yang paling berperan dalam meningkatkan pelayanan terhadap konsumen. Pengujian dilakukan dua kali, pengujian pertama dilakukan untuk menguji hipotesis pertama dan pengujian kedua dilakukan untuk menguji hipotesis kedua. Model pengujian hipotesis disajikan pada gambar berikut:

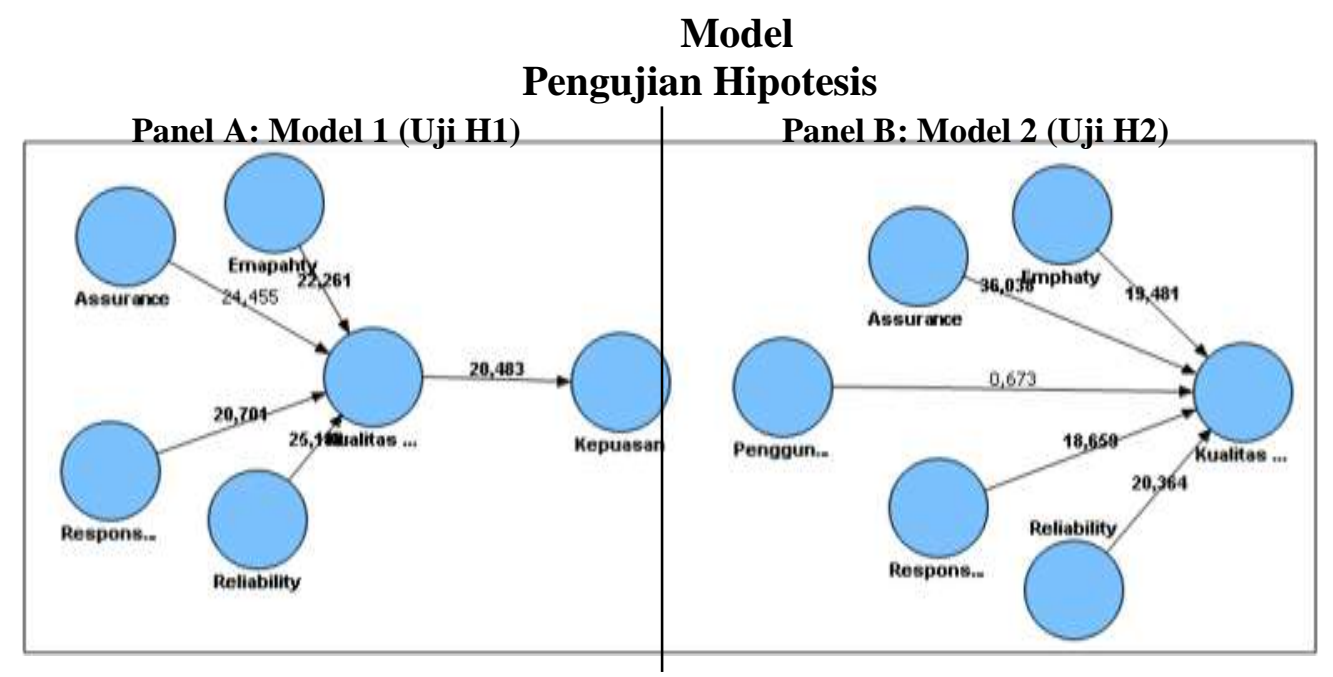

. Model yang disajikan pada gambar tersebut diatas digunakan untuk menguji seluruh hipotesis yang diajukan. Adapun hasil pengujian hipotesis disajikan pada tabel 2 berikut :

Tabel 2

Hasil uji hipotesis Panel A: Hasil Uji Model 1

\begin{tabular}{|l|l|l|l|}
\hline Hubungan Antar Variabel & Koefisien & t-value & $\begin{array}{l}\text { p- } \\
\text { value }\end{array}$ \\
\hline
\end{tabular}




\begin{tabular}{|c|c|c|c|}
\hline Penggunaan TI -> Kualitas pelayanan & $-0,00223$ & 0,899123 & 0,3707 \\
\hline Assurance -> Kualitas pelayanan & 0,347794 & 35,16619 & 0,0000 \\
\hline Emphaty $->$ Kualitas pelayanan & 0,327009 & 20,53898 & 0,0000 \\
\hline Reliability $->$ Kualitas pelayanan & 0,174963 & 22,43117 & 0,0000 \\
\hline Responsiveness -> Kualitas pelayanan & 0,243199 & 15,1343 & 0,0000 \\
\hline \multicolumn{4}{|c|}{ Panel B: Hasil Uji Model 2} \\
\hline Hubungan Antar Variabel & Koefisien & t-value & $\begin{array}{l}\text { p- } \\
\text { value }\end{array}$ \\
\hline Kualitas Pelayanan -> Kepuasan & 0,77585 & 20,48291 & 0,0000 \\
\hline Assurance $->$ Kualitas Pelayanan & 0,285715 & 24,4552 & 0,0000 \\
\hline Emapahty -> Kualitas Pelayanan & 0,310352 & 22,26069 & 0,0000 \\
\hline Reliability -> Kualitas Pelayanan & 0,249205 & 25,17996 & 0,0000 \\
\hline Responsiveness -> Kualitas Pelayanan & 0,256833 & 20,70129 & 0,0000 \\
\hline
\end{tabular}

Hasil analisis tersebut diatas menunjukkan bahwa tidak terdapat pengaruh singnifikan pemanfaatan teknologi informasi terhadap kualitas pelayanan pegawai administrasi di lingkungan FISE UNY . Hal tersebut di tunjukkan dengan nilai koefisien sebesar -0,00223, nilai t-value sebesar 0,899123 dan nilai $\mathrm{p}$-value sebesar $\mathrm{p}$-value $=0,3707$ sehingga hipotetis pertama yang menyatakan Pemanfaatan Teknologi Informasi Berpengaruh Terhadap Kualitas Pelayanan Pegawai Administrasi Di Lingkungan FISE UNY ditolak / tidak dapat diterima. Sedangkan untuk pengujian hipotesis kedua menunjukkan bahwa terdapat pengaruh positif dan signifikan antara kualitas pelayanan dengan kepuasan. Hal tersebut di tunjukkan dengan nilai koefisien sebesar 0,77585, nilai t-value sebesar 20,48291 dan nilai p-value sebesar 0,000. Dari hasil tersebut, maka dapat disimpulkan bahwa hipotesis kedua yang menyatakan Kualitas Pelayanan Pegawai Administrasi Berpengaruh Terhadap Kepuasan Mahasiswa Di Lingkungan FISE UNY diterima.

\subsection{Pembahasan}

Hasil uji hipotesis pertama menunjukan bahwa tidak terdapat pengaruh antara pemanfaatan teknologi terhadap kualitas pelayanan yang diberikan. Kondisi tersebut menunjukan bahwa $\mathrm{H} 1$ ditolak/tidak dapat diterima. Fenomena ini bertolak belakang dengan kajian penelitian terdahulu yang digunakan untuk membangun hipotesis yang menyatakan bahwa pemanfaatan teknologi informasi akan meningkatkan kinerja yang yang dalam konteks penelitian ini adalah peningkatan kualitas pelayanan yang diberikan. Penolakan ini terjadi karena dalam komponen yang membangun kualitas pelayanan selain pemanfaatan teknologi informasi (assurance, Empathy, reliability, dan responsiveness) memberikan pengaruh positive signifikan $(\mathrm{p}>0.000)$ terhadap kualitas pelayanan baik di model 1 maupun di model 2 (lihat tabel 7). Keempat komponen tersebut mengindikasikan performa individu berperan lebih terhadap kualitas pelayanan daripada pemanfaatan TI.

Kuatnya performa individu dalam peningkatan kualitas pelayanan juga ditunjukkan dari data jawaban responden mengenai terdapatnya kebersediaan pegawai administratif melayani mahasiswa meskipun $70 \%$ responden menganggap mahasiswa cenderung bersikap kurang sopan ketika berinteraksi dengan karyawan. Selain itu, tidak terdapatnya pengaruh pemanfaatan teknologi informasi terhadap kualitas pelayanan dapat dijelaskan dari data jawaban responden yang menunjukkan bahwa mahasiswa ketika berinteraksi dengan pegawai administrasi adalah untuk mengurus kelengkapan akademik (76 \% ) dan mengurus kelengkapan administrasi (76 \%) dimana jenis pelayanan tersebut tidak memerlukan pemanfaatan teknologi infomasi sehingga pengaruh pemanfaatan teknologi informasi terhadap kualitas pelayanan yang berkaitan dengan kelengkapan akademik dan administrasi 
tidak signifikan. Berdasarkan data jawaban responden yang berkaitan dengan waktu yang digunakan oleh pegawai dalam menggunakan komputer untuk melayani / memberi informasi kepada mahasiswa, sebagian besar responden $(36,37 \%)$ menjawab waktu yang digunakan adalah antara 5 -10 menit. Hal tersebut menunjukkan bahwa pegawai administrasi tidak membutuhkan waktu yang lama dalam memanfaatkan teknologi informasi untuk melayani mahasiswa, sehingga memberikan indikasi bahwa pegawai administrasi kurang optimal dalam memanfaatkan teknologi informasi untuk melayani mahasiswa.

Hasil pengujian hipotesis kedua menunjukkan bahwa kualitas pelayanan pegawai administrasi berpengaruh terhadap kepuasan mahasiswa di lingkungan FISE UNY. Hasil tersebut sesuai dengan kajian teori yang telah dikemukakan pada bab sebelumnya bahwa kualitas pelayanan mempengaruhi kepuasan. Hasil penelitian ini didukung oleh penelitian yang dilakuan oleh Scotti (2007) yang menemukana bahwa kualitas pelayanan berhubungan dengan kepuasan konsumen. Kepuasan konsumen terjadi jika konsumen menggunakan kembali layanan dan menyarankan orang lain untuk menggunakan layanan tersebut. Berdasarkan hasil penelitian ini mengimplikasikan bahwa puas tidaknya mahasiswa terhadap pelayanan yang diberikan tergantung pada kualitas pelayanan yang diberikan oleh pegawai administrasi dilingkungan FISE UNY. Sehingga pimpinan fakultas hendaknya meningkatkan kualitas pelayanan pegawai administrasi dengan peningkatan kegiatan pendidikan dan pengembangan pegawai administrasi dalam hal pelayananan kepada mahasiswa.

\section{KESIMPULAN DAN SARAN}

\subsection{Kesimpulan}

1. Pemanfaatan Teknologi Informasi tidak Berpengaruh Terhadap Kualitas Pelayanan Pegawai Administrasi Di Lingkungan FISE UNY . Hal ini ditunjukkan dengan nilai koefisien sebesar -0,00223, nilai t-value sebesar 0,899123 dan nilai p-value sebesar 0,3707 . Tidak diterimanya hipotesis dalam penelitian ini karena performa individu lebih berperan pada kualitas pelayanan dibanding dengan pemanfaatan teknologi informasi, penggunaan teknologi informasi dalam pelayanan menjadi alternatif pilihan ketika menghadapi jenis pelayanan yang tidak membutuhkan teknologi informasi.

2. Kualitas Pelayanan Pegawai Administrasi Berpengaruh Terhadap Kepuasan Mahasiswa Di Lingkungan FISE UNY. Hal ini ditunjukkan dengan nilai koefisien 0,787333 nilai t-value sebesar 41,072917 dan nilai p-value sebesar 0,0000 .

\subsection{Keterbatasan}

Penelitian ini memiliki beberapa keterbatasan sebagai berikut:

1. Sampel penelitian kurang besar karena cakupan penelitian sempit sehingga mengurangi validitas external penelitian.

2. Bias dari teknik survei karena bersifat self-reporting

3. Penelitian ini kurang konsisten dalam penggunaan populasi atau sampel. Untuk menjawab hipotesis pertama menggunakan populasi sedangkan untuk menjawab hipotesis kedua menggunakan sampel.

\subsection{Saran}

Beberapa saran yang dapat diajukan dalam penelitian selanjutnya adalah:

1. Cakupan penelitian sebaiknya diperluas sehingga dapat meningkatkan validitas ekternal dari penelitian.

2. Hendaknya lebih konsisten dalam pengambilan populasi atau sampel dalam satu penelitian, jika sample ya sampel semua dan jika populasi ya populasi . 
3. Penelitian selanjutnya sebaiknya mempertimbangkan peran teknologi informasi dalam pelayanan. Apakah sebagai komponen utama dalam pelayanan atau hanya sebagai pendukung dalam pelayanan.

\section{DAFTAR PUSTAKA}

Banwet, D.K dan Datta B. Effect of Service Quality On Post - Visit Intentons Over Time : The Case of A Library. Total Quality Management. Vol 13 No 4. 2002. pp. 537-546.

Barger P.B dan Grandey. A.A. Service With A Smal An Encounter Satisfaction : Emotional Contagion And Appraisal Mechanisms. Academy of Management Journal. Vol 49 No 6. 2006. pp. 1229-1238

Beatson A. et al, "Satisfaction and Commitment Through Self-Service Technology and Personal Service Usage”, Journal of Marketing Management, (Vol. 22), 2006, pp. 853882

Bodnar dan Hopwood. Accounting Information System. Prentice Hall Inc. 1995

Chin W. W. "Commentary: Issues and Opinion on Structural Equation Modeling" MIS Quarterly, March 1998, pp. vii-xvi

Erdfelder, E. et al, "GPOWER: A general power analysis program" Behavior Research Methods, Instruments, \& Computers, (Vol.28 No.1), 1996,pp. 1-11

Gefen, et al "Structural Equation Modeling Techniques and Regression: Guidelines For Research Practice" Communications of AIS (Vol. 4, Article 7), 2000

Hair, J. E., et al., Multivariate Data Analysis With Reading, Prentice-Hall International, $4^{\text {th }}$ Ed., 1995.

Hauser, R. dan Paul, R., "Is Service Quality And Culture: An Empirical Investigation," Journal of Computer Information Systems, Fall 2006, pp.15-22.

Ho, V. T; et al. "When Subordinates Become IT Contractors: Persistent Managerial Expectations in IT Outsourcing", Information Systems Research, (Vol. 14, No. 1), March 2003, pp. 66-86

Iivari, J. "An Empirical Test of DeLone-McLean model Of information System Success ," The DATA BASE for Advances in Information Systems, (36:2), Spring 2005, pp. 8-27

Jogiyanto dan Abdillah, W. Konsep \& Aplikasi PLS Untuk Penelitian Empiris, BPFE Yogyakarta, 2009

Kustono, A.S, "Motivasi Perataan Penghasilan" Jurnal Riset akuntansi Indonesia, (Vol. 11, No.2), 2008, pp. 133-157

Mahendra, Kesuksesan Katalog Elektronik Perpustakaan Akademik : Pengaruh Ketakutan Komputer, Pemakai dan Kualitas Pelayanan Pustakawan Dengan Kualitas dan Kualitas Informasi Sebagai Variabel Kendali. Tesis S2 Program Studi Akuntansi Pasca Sarjana UGM. 2008 
Quinn, B. "Adapting Service Quality Concepts to Academic Libraries" The Journal Of academic Librarianship, (September), 1997, pp. 359-369

Roach S. Service Under Siege : The Restructuring Imperative. Harvard Business Review. September-Oktober. 1991

Romney. B Marshall. Accounting Information System (Siatem Informasi Akuntansi). Edisi 9 (Edisi Bahasa Indonesia). Buku 1. Salemba Empat. 2006.

Sahu, A. K., "Perceptions Of Service Quality In An Academic Library: A Case Study" Journal of Services Research, (Vol. 6, No. 1), April - September 2006, pp. 1887-204

Scotti, D J. Link Among High Performance Work Environment, Service Quality and Customer Satisfaction : An Extention To The Healthcare Sector. Journal of Healthcare Management. (52: 2). March/April 2007. pp. 109-124

Strassman Paul Spending without Result. Computerworld.April 1996

Sukanti. Analisis Kepuasan Mahasiswa Program Studi Pendidikan Akuntansi. Hasil Penelitian Yang di Danai Fakultas. 2008.

Ta-tugasakhir.blogspot.com/2007/10/ Konsep-Kepuasan-Konsumen. Diakses 28 Februari 2010.

Teddy Jurnali. Analisis Pengaruh Faktor Kesesuaian Tugas-Teknologi dan Pemanfaatan Teknologi Informasi Terhadap Kinerja Akuntan Publik. Simposium Nasional Akuntansi IV. 2001

Temme, d. Et al "PLS path modeling a software review. SFB 649 Discussion paper" http://www.stasoft.com/textbook, 2006

Thai Fung Jin. (2002). Analisis Faktor-Faktor yang Mempengaruhi Pemanfaatan Teknologi Informasi dan Pengaruh Pemanfaatan Teknologi Informasi Terhadap Kinerja Akuntan Publik. Tesis S-2 UGM. 2002.

Thompson Ronald, Christoper A and Howell Jane. (1991). Personal Computing : Toward a Conceptual Model of Utilization. MIS Quarterly. March 1991

Thompson Ronald, Christoper A and Howell Jane. (1994). Influence of Experience on Personal Computer Utilization : testing A Conceptual Model. Journal of Management Information Systems. 1994

Tjiptono, Fandy. Manajemen Jasa. Yogyakarta. Penerbit Andi. 1996 